\title{
Chassis Device
}

National Cancer Institute

\section{Source}

National Cancer Institute. Chassis Device. NCI Thesaurus. Code C49869.

A supporting frame designed to hold other components or devices such as the chassis of a car or the internal frame of an electronic device. 